\title{
WERYFIKACJA MOŻLIWOŚCI ZASTOSOWANIA WSKAŹNIKA ITS DO OCENY STANU TROFICZNEGO ZBIORNIKA DOBCZYCKIEGO
}

\begin{abstract}
W ostatnich latach problem eutrofizacji stał się powszechny nie tylko w wodach stojących ale także w płynących. Budzi on spore zainteresowanie zwłaszcza gdy zaczyna dotyczyć wód przeznaczonych do zaopatrzenia ludzi w wodę do spożycia. Zbiornik Dobczycki o którym traktuje artykuł jest właśnie takim rezerwuarem. Tu ujmowana jest woda dla mieszkańców Krakowa. W literaturze spotyka się stwierdzenia, że wody zbiornika zawsze były podatne na eutrofizację ze względu na ładunki biogenów które są wnoszone do niego przez Rabę. Problem oceny stopnia eutrofizacji Zbiornika Dobczyckiego został więc podjęty nie tyle ze względów poznawczych, co utylitarnych. Wymagał rzetelnej i szczegółowej analizy danych pomiarowych pochodzących z monitoringu. Do oceny zjawiska eutrofizacji wykorzystano integralny wskaźnik troficzności ITS. Jest on jednym z coraz powszechniej stosowanych obecnie zagregowanych wskaźników. Dostrzeżono że graniczne wartości pojedynczych parametrów niekoniecznie odzwierciedlają stan trofii i uprawniają do wnioskowania o zjawisku eutrofizacji. Zastosowanie wskaźnika ITS wiąże się z wykorzystaniem parametrów takich jak $\mathrm{pH}$ i nasycenie wody tlenem, które odzwierciedlają bilans gazowy w wodach, zmieniający się wraz ze zmianą bilansu procesów produkcji i rozkładu materii organicznej. Nie wymaga on więc szczegółowych oznaczeń monitoringowych, przez co może być wykorzystywany jako uniwersalny sposób oceny trofii. W artykule uzasadniono wybór wskaźnika ITS jako metody oceny trofii na podstawie analizy statystycznej danych monitoringu Zbiornika pochodzących $\mathrm{z}$ okresu wieloletniego. Uwiarygodniło to ocenę i pozwoliło dostrzec pewne prawidłowości procesu oraz jego dynamikę. $\mathrm{Na}$ jej podstawie możliwa jest prognoza prawdopodobnego scenariusza dalszego rozwoju zjawiska. Utrzymujący się w minionych 15 latach stan pograniczny zaawansowanej mezotrofii/eutrofii przy jednoczesnej dobrej jakości użytkowej wód pozwala na stwierdzenie stabilizacji stanu ekologicznego Zbiornika Dobczyckiego.
\end{abstract}

\footnotetext{
${ }^{1}$ Elena Neverova-Dziopak, Akademia Górniczo-Hutnicza, Wydział Geodezji Górniczej i Inżynierii Środowiska, Katedra Kształtowania i Ochrony Środowiska, al. Mickiewicza 30 30-059 Kraków, tel.: +48 (12) 61747 04, e-mail: elena@agh.edu.pl

2 Autor do korespondencji / corresponding author: Anna Droździk, Uniwersytet Rolniczy im. H. Kołłątaja w Krakowie, Wydział Leśny, Instytut Ochrony Ekosystemów Leśnych, Zakład Inżynierii Leśnej, al. 29 Listopada 46 31-425 Kraków, tel.: + 48 (12) 66251 11, e-mail: a.drozdzik@ur.krakow.pl
} 
Słowa kluczowe: Zbiornik Dobczycki, eutrofizacja, Integralny Wskaźnik Troficzności (ITS), analiza statystyczna

\section{Wprowadzenie}

Obiekty gromadzące i magazynujące wodę przeznaczoną do spożycia skupiają na sobie szczególną uwagę zarówno służb prowadzących monitoring, jak i finalnych odbiorców. Decyzje dotyczące jakichkolwiek zmian użytkowania są szeroko komentowane i niejednokrotnie budzą wielkie emocje, dlatego też odpowiednie gospodarowanie zasobami wodnymi powinno uwzględniać także analizę istniejących przesłanek skłaniających do podjęcia takiej a nie innej decyzji. Dotyczy to przede wszystkim działań mogących w jakikolwiek sposób wpływać na jakość retencjonowanej wody, będącej priorytetem prowadzonej działalności.

W ostatnich latach narasta problem eutrofizacji wód powierzchniowych. Dotyczy on głównie wód stojących, ale coraz częściej zaczyna stanowić zagrożenie również w rzekach. Stając się zjawiskiem powszechnym oraz ze względu na następstwa niebezpiecznym dla człowieka, wymaga przemyślanych i szybkich działań zaradczych. Proces ten jest coraz szerzej badany i przez to poznawany, jednak mimo to ciągle do końca niewyjaśniony [23]. Jego złożoność i wieloaspektowość wymaga regularnego monitoringu. Wnioskowanie o stopniu zaawansowania eutrofizacji na podstawie danych monitoringowych wymaga z kolei stosowania wiarygodnych metod oceny. Metody te bazują na tradycyjnych wskaźnikach eutrofizacji i mają charakter opisowy lub też oparte są na wskaźnikach zagregowanych [20]. Wieloaspektowość zjawiska eutrofizacji wymaga $\mathrm{z}$ reguły dopasowania poszczególnych metod oceny do konkretnych akwenów wodnych. Nie ma bowiem wskaźników uniwersalnych, a specyfika danego obszaru wymusza indywidualne podejście do każdego przypadku. Modyfikowanie i doskonalenie narzędzi oceny wynika z rozwoju wiedzy na temat funkcjonowania ekosystemu jako całości, ale nie bez znaczenia są również względy ekonomiczne. Wiele istniejących metod wymaga drogich, pracochłonnych i czasochłonnych badań, które dodatkowo komplikują realizację regularnego monitoringu eutrofizacji i śledzenie bieżących zmian. Potrzebne są metody proste, szybkie i tanie.

Pod względem zaawansowania procesów eutrofizacji, wody dzieli się zasadniczo na oligotroficzne, mezotroficzne i eutroficzne. Przynależność wód do tej lub innej kategorii ustala się na podstawie kryteriów opracowanych przez różnych autorów $\mathrm{w}$ różnych regionach świata. $\mathrm{W}$ związku $\mathrm{z}$ tym powstają spore trudności w interpretowaniu stanu troficznego wód powierzchniowych. Spośród wielu metod oceny trofii, najbardziej rozpowszechniona i tradycyjnie stosowana jest ocena według granicznych wartości pojedynczych parametrów, np. fosforu ogólnego, azotu ogólnego, chlorofilu „a”, widzialności krążka Secchiego [13]. Współczesne podejście preferuje stosowanie wskaźników zagregowanych czyli 
wykorzystujących wzajemne relacje kilku parametrów. Do takich należy indeks TSI (Trophic State Index) oparty na przezroczystości wody, chlorofilu-a oraz fosforze ogólnym [7, 10], indeks TRIX (Trophic index) który wykorzystuje czynniki świadczące o produktywności (chlorofil-a, nasycenie wody tlenem jego odchylenie od $100 \%$ nasycenia), zawartość nutrietów i jako czynnik uzupełniający przezroczystość wody (wyrażoną widocznością krążka Secchiego) [26]. Oprócz wyżej wymienionych istnieje cały szereg metod oceny stanu troficzności opracowanych przez różnych autorów, jednak ich zastosowanie wymaga weryfikacji dla warunków polskich.

Większość wskaźników zagregowanych bazuje na parametrach charakteryzujących procesy produkcji biomasy roślinności wodnej. Poziom trofii jest natomiast uwarunkowany bilansem procesów produkcji i rozkładu materii organicznej wytwarzanej przez glony. Wskaźnikiem który w sposób integralny odzwierciedla ten bilans jest wskaźnik ITS (Index of Trophical State) bazujący na fundamentalnych mechanizmach przebiegu eutrofizacji. Odzwierciedla on zmiany bilansu tlenu i dwutlenku węgla poprzez rutynowo badane wskaźniki jakości wody [20].

\section{Obszar badań i baza danych}

Obszar badań stanowił Zbiornik Dobczycki retencjonujący wody dla potrzeb aglomeracji krakowskiej. Należy on do regionu wodnego zarządzanego przez Regionalny Zarząd Gospodarki Wodnej w Krakowie. Monitoring jakości jego wód realizowany jest przez Wojewódzki Inspektorat Ochrony Środowiska w Krakowie. Zbiornik piętrzy wody rzeki Raba w $60,1 \mathrm{~km}$ jej biegu. Powierzchnia lustra wody przy maksymalnym poziomie piętrzenia wynosi 1011 ha i odpowiada pojemności maksymalnej równej $137,95 \mathrm{mln}^{3}$. Powierzchnia jego zlewni wynosi $768,0 \mathrm{~km}^{2}$ [24]. Powierzchnia zlewni bezpośredniej to $72,0 \mathrm{~km}^{2}$. Zbiornik uznawany jest za głęboki, jego średnia głębokość to $11,0 \mathrm{~m}$. Wymiana wody zachodzi trzy i pół razy w ciągu roku [30]. Struktura użytkowania zlewni przedstawia się następująco: 53\% użytki rolne, 44\% lasy, 1,6\% osiedla ludzkie [9], a duże nachylenia zboczy sprzyjają formowaniu się spływu powierzchniowego [16]. Zbiornik zlokalizowany jest w południowej Polsce, na pograniczu Beskidu Makowskiego i Pogórza Wielickiego. Zgodnie z danymi IMGW dla Krakowa [8] wartości średnie roczne z wielolecia 1981-2010 wynoszą: w przypadku sumy opadów $671,9 \mathrm{~mm}$ (najwyższa wieloletnia suma miesięczna przypada na lipiec - średnio $87,9 \mathrm{~mm}$, najniższa na luty - średnio $29,7 \mathrm{~mm}$ ), w przypadku temperatury $8,5^{\circ} \mathrm{C}$ (najcieplejszy miesiąc to lipiec ze średnią wieloletnią $18,8^{\circ} \mathrm{C}$, najchłodniejszy jest styczeń - średnio $2,1^{\circ} \mathrm{C}$ ). Cebulska i in. [5] piszą natomiast o $881 \mathrm{~mm}$ jako średnim rocznym opadzie wielolecia 1952-1981.

Bazę danych do analiz stworzono na podstawie wyników pomiarów wykonywanych przez służby monitoringowe Wojewódzkiego Inspektoratu Ochrony Środowiska w Krakowie w ramach prowadzonego Państwowego Monitoringu 
Środowiska [27]. Analizę oparto na wartościach dwóch parametrów fizykochemicznych wchodzących w skład równania do obliczania wartości ITS: pH i nasycenia wody tlenem [20]. Baza danych obejmowała pomiary uzyskane z 15letniego monitoringu prowadzonego w okresie 2000-2014, a próbki wody pobierane były w trzech punktach pomiarowo-kontrolnych. Pierwszym i jednocześnie strategicznym punktem pomiarowo-kontrolnym (1 ppk) było stanowisko w miejscu ujęcia wieżowego. Drugi punkt pomiarowo-kontrolny (2 ppk) zlokalizowano na środku Zbiornika, natomiast trzeci ( $3 \mathrm{ppk}$ ) zlokalizowano przy upuście dennym zapory. Próbki wody pochodziły z trzech głębokości: warstwy powierzchniowej, warstwy zlokalizowanej $3 \mathrm{~m}$ pod powierzchnią wody i warstwy naddennej. Lokalizację punktów pomiarowo-kontrolnych na Zbiorniku Dobczyckim obrazuje poniższy rysunek (Rys. 1).

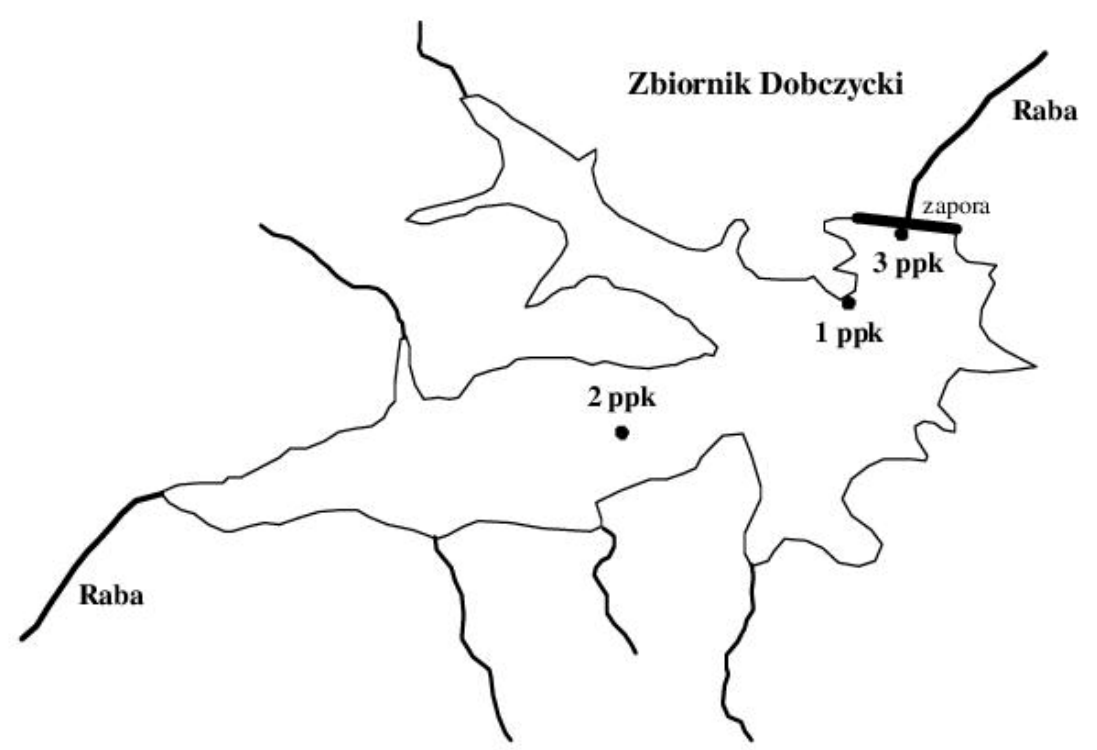

Rys. 1. Lokalizacja punktów pomiarowo-kontrolnych na Zbiorniku Dobczyckim

Fig. 1. Localization of measurement-control points at Dobczycki Reservoir

\section{Metodyka badań}

Metodologia badań była oparta na analizie korelacyjnej i regresyjnej danych wieloletniego monitoringu z wykorzystaniem pakietu STATISTICA 12.5 firmy StatSoft Polska. Ocena stanu troficznego bazowała na integralnym wskaźniku troficzności ITS opartym na liniowej zależności korelacyjnej między wartościami $\mathrm{pH}$ wody a jej nasyceniem tlenem. Wybór tej metody oceny wymagał uzasadnienia wynikami analizy statystycznej (korelacyjnej) celem ustalenia charakteru zależności pomiędzy pH a nasyceniem wody tlenem. Istotność korelacji 
określano na podstawie wartości współczynnika Pearsona, a interpretację wyników przyjęto zgodnie z danymi literaturowymi [18]. Korelację uznano za istotną przy wartości współczynnika korelacji (r) powyżej 0,6 oznaczającej silny związek między parametrami. W wyniku przeprowadzonej analizy statystycznej ustalono liniowy charakter zależności między $\mathrm{pH}$ i nasyceniem wody tlenem oraz stwierdzono istotną zależność badanych parametrów. Umożliwiło to zastosowanie wskaźnika ITS do określenia stanu troficznego Zbiornika Dobczyckiego zgodnie z równaniem (1) [20]:

$$
\mathrm{ITS}=\frac{\Sigma \mathrm{pH}_{\mathrm{i}}}{n}+a \cdot\left(100-\frac{\Sigma\left[\mathrm{O}_{2} \%\right]}{n}\right)
$$

gdzie: $\mathrm{pH}_{\mathrm{i}}-$ wartość $\mathrm{pH}$ wody,

$\mathrm{O}_{2} \%$ - nasycenie wody tlenem mierzone synchronicznie $\mathrm{z} \mathrm{pH}$,

$a$ - współczynnik empiryczny,

$n$ - liczba pomiarów w badanym okresie.

Normatywne wartości wskaźnika ITS dla wód o różnym stanie troficzności przedstawia Tabela 1.

Tabela 1. Wartości wskaźnika ITS dla typów troficznych wód (na podstawie [20])

Table 1. Values of ITS index for trophic types of water (based on [20])

\begin{tabular}{|c|c|}
\hline Wartość ITS & Ocena stanu trofii \\
\hline$<6,0$ & dystrofia \\
$6,3 \pm 0,3$ & ultraoligotrofia \\
$7,0 \pm 0,3$ & oligotrofia \\
$7,7 \pm 0,3$ & mezotrofia \\
$8,3 \pm 0,3$ & eutrofia \\
\hline
\end{tabular}

Zastosowanie powyższego wskaźnika pozwoliło na zbadanie wieloletniej dynamiki zmian stanu troficznego Zbiornika Dobczyckiego, w sytuacji istotnego braku regularnego monitoringu tradycyjnych wskaźników eutrofizacji w badanym okresie.

\section{Analiza wyników i dyskusja}

Baza danych do analizy statystycznej obejmowała łącznie 1216 wyników pomiarów (608 pH i $608 \% \mathrm{O}_{2}$ ). Analizę przeprowadzono dla okresu wegetacyjnego (maj-październik) i okresu rocznego dla wszystkich trzech poziomówgłębokości z których pobierano próbki: samej warstwy powierzchniowej, warstwy powierzchniowej łącznie $\mathrm{z}$ warstwą $3 \mathrm{~m}$ poniżej powierzchni - stanowiących warstwę fotyczną [29] oraz całego profilu głębokościowego Zbiornika 
(trzech warstw pomiarowych). W taki sposób wydzielono 6 przypadków (tab. 2), dla których następnie przeprowadzono analizę korelacyjno-regresyjną zależności $\mathrm{pH}$ i nasycenia wody tlenem. Zależności ustalano dla całego okresu badawczego 2000-2014, jak również dla poszczególnych lat. W każdym z sześciu analizowanych przypadków rok 2012 znacząco odróżniał się od pozostałych niską i w dodatku ujemną korelacją. Fakt zupełnej i niewyjaśnionej odmienności zdecydował o wykluczeniu go z analiz dla wielolecia.

Tabela 2. Sześć przypadków wydzielonych do analiz korelacyjno-regresyjnych

Table 2. The six separate cases for correlation and regression analyses

\begin{tabular}{|c|c|c|c|}
\hline Okres badawczy & $\begin{array}{c}\text { Warstwa } \\
\text { powierzchniowa }\end{array}$ & $\begin{array}{c}\text { Warstwa } \\
\text { Wowierzchniowa } \\
\text { + warstwa 3 m } \\
\text { poniżej } \\
\text { powierzchni } \\
\text { powierzchniowa } \\
\text { + warstwa 3 m } \\
\text { poniżej } \\
\text { powierzchni } \\
\text { + warstwa } \\
\text { naddenna } \\
\text { (cały profil) }\end{array}$ \\
\hline $\begin{array}{c}\text { Cały rok } \\
\text { Okres } \\
\text { wegetacyjny } \\
\text { (V-X) }\end{array}$ & $(1)$ & $(3)$ & $(5)$ \\
\hline
\end{tabular}

Zestawienie wartości współczynników korelacji Pearsona charakteryzujących istotność korelacji między pH a nasyceniem wody tlenem (dla badanych okresów i lokalizacji punktów pomiarowo-kontrolnych) przedstawia tabela 3.

Wybrane wykresy zależności $\mathrm{pH}$ od nasycenia wody tlenem przedstawia rysunek 2.

Analiza rozrzutu punktów na wykresach oraz wartości współczynników korelacji pozwoliła na jednoznaczne stwierdzenie liniowego charakteru zależności pH od nasycenia wody tlenem w Zbiorniku Dobczyckim. O wysokim stopniu jej istotności świadczą wyniki analizy przeprowadzonej dla wszystkich sześciu przypadków, zarówno dla całego 15-letniego okresu badawczego, jak i dla poszczególnych lat. Trzeba zaznaczyć, że korelacje wartości pH i nasycenia wody tlenem są najistotniejsze dla całego profilu badawczego, tj. przy uwzględnieniu wszystkich warstw pomiarowych. Odzwierciedla to fakt występowania w Zbiorniku Dobczyckim strefy fotycznej na znacznych głębokościach - $2 \mathrm{~m}$ w cofce zbiornika i $10 \mathrm{~m}$ w Basenie Dobczyckim - przy średniej głębokości Zbiornika $11 \mathrm{~m}$ [29], jak również pionowych migracji fitoplanktonu w słupie wody $[19,15,25]$. Ściślejsza korelacja występuje przy analizie statystycznej danych pochodzących z okresu wegetacyjnego (okres od maja do października). Współczynniki korelacji uzyskane na podstawie danych z 15-letniego monito- 
ringu (2000-2014) wynoszą odpowiednio: dla okresu całorocznego $\mathrm{r}=0,64$, dla okresu wegetacyjnego $\mathrm{r}=0,70$ (tab. 3 ).

Tabela 3. Współczynniki korelacji (r) dla poszczególnych przypadków z tabeli 2

Table 3. The correlation coefficients ( $r$ ) for the cases from table 2

\begin{tabular}{|c|c|c|c|c|c|c|}
\hline \multirow{2}{*}{$\begin{array}{c}\text { Okres } \\
\text { badawczy }\end{array}$} & \multicolumn{2}{|c|}{$\begin{array}{c}\text { Warstwa } \\
\text { powierzchniowa }\end{array}$} & \multicolumn{2}{c|}{$\begin{array}{c}\text { Warstwa powierzch- } \\
\text { niowa + warstwa 3 m } \\
\text { poniżej powierzchni }\end{array}$} & $\begin{array}{c}\text { Warstwa powierzch- } \\
\text { niowa + warstwa 3 m } \\
\text { poniżej powierzchni } \\
\text { + warstwa naddenna } \\
\text { (cały profil) }\end{array}$ \\
\cline { 2 - 8 } & Cały rok & $\begin{array}{c}\text { O. weget. } \\
\text { (V-X) }\end{array}$ & Cały rok & $\begin{array}{c}\text { O. weget. } \\
\text { (V-X) }\end{array}$ & Cały rok & $\begin{array}{c}\text { O. weget. } \\
\text { (V-X) }\end{array}$ \\
\hline $\begin{array}{c}\text { Numer } \\
\text { przypadku }\end{array}$ & $(1)$ & $(2)$ & $(3)$ & $(4)$ & $(5)$ & $(6)$ \\
\hline 2000 & 0,30 & $-0,03$ & 0,40 & 0,04 & 0,65 & $\mathbf{0 , 6 8}$ \\
\hline 2001 & 0,91 & $\mathbf{0 , 9 3}$ & 0,88 & 0,91 & 0,87 & 0,88 \\
\hline 2002 & 0,56 & 0,50 & 0,53 & 0,45 & 0,56 & $\mathbf{0 , 7 2}$ \\
\hline 2003 & 0,80 & $\mathbf{0 , 8 4}$ & 0,77 & 0,80 & 0,72 & 0,80 \\
\hline 2004 & 0,52 & 0,42 & 0,37 & 0,41 & 0,51 & $\mathbf{0 , 7 3}$ \\
\hline 2005 & 0,61 & 0,58 & 0,61 & 0,64 & 0,67 & $\mathbf{0 , 8 0}$ \\
\hline 2006 & 0,68 & 0,65 & 0,70 & 0,78 & 0,77 & $\mathbf{0 , 9 0}$ \\
\hline 2007 & $\mathbf{0 , 7 1}$ & 0,55 & 0,68 & 0,53 & 0,62 & 0,59 \\
\hline 2008 & 0,80 & 0,62 & 0,74 & 0,80 & 0,77 & $\mathbf{0 , 9 0}$ \\
\hline 2009 & 0,76 & 0,52 & 0,66 & 0,65 & 0,54 & $\mathbf{0 , 8 0}$ \\
\hline 2010 & 0,79 & 0,81 & 0,82 & $\mathbf{0 , 8 4}$ & 0,81 & $\mathbf{0 , 8 4}$ \\
\hline 2011 & 0,76 & 0,40 & 0,72 & 0,15 & 0,84 & $\mathbf{0 , 8 7}$ \\
\hline 2012 & $-0,27$ & $-0,41$ & $-0,27$ & $-0,41$ & $-0,27$ & $-0,41$ \\
\hline 2013 & 0,86 & $\mathbf{0 , 9 8}$ & 0,86 & $\mathbf{0 , 9 8}$ & 0,86 & $\mathbf{0 , 9 8}$ \\
\hline 2014 & 0,75 & $\mathbf{0 , 8 0}$ & 0,75 & $\mathbf{0 , 8 0}$ & 0,75 & 0,78 \\
\hline $2000-$ & 0,55 & 0,44 & 0,56 & 0,47 & 0,63 & $\mathbf{0 , 7 0}$ \\
\hline 2014 & $0,57 *$ & $0,45^{*}$ & $0,56 *$ & $0,48^{*}$ & $0,64 *$ & $\mathbf{0 , 7 0 *}$ \\
\hline
\end{tabular}

* - wyniki dla sytuacji w której rok 2012 był wykluczony $\mathrm{z}$ analiz dla wielolecia 2000-2014

* - the results for the situation when the year 2012 was excluded from the analysis in 2000-2014 period 
Wykres rozrzutu $\mathrm{pH}$ względem $\% \mathrm{O} 2$

$200110 \mathrm{v} * 31 \mathrm{c}$

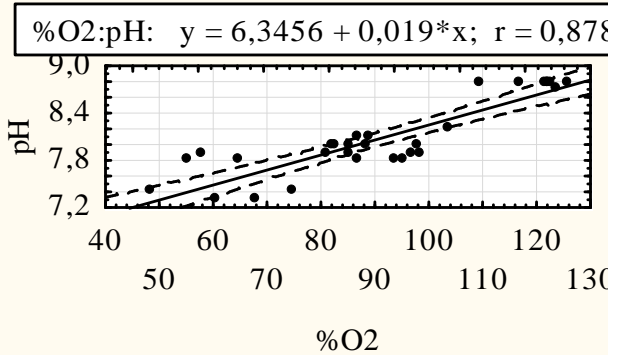

Wykres rozrzutu $\mathrm{pH}$ względem \%O2

$200810 \mathrm{v} * 19 \mathrm{c}$

$\%$ O2:pH: $\quad \mathrm{y}=7,4597+0,0092 * x ;$. Ufn.

$\mathrm{r}=0,8997 ; \mathrm{p}=0,00000$

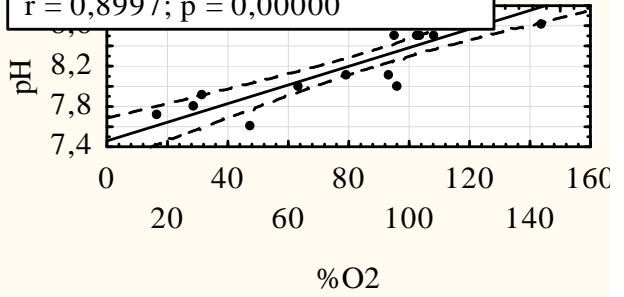

Wykres rozrzutu $\mathrm{pH}$ względem \%O2

$200610 \mathrm{v} * 19 \mathrm{c}$

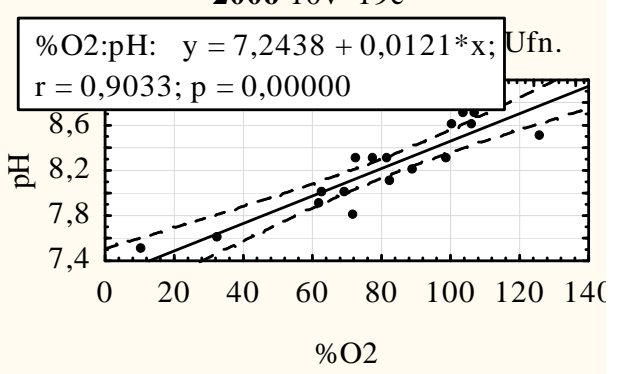

Wykres rozrzutu $\mathrm{pH}$ względem \%O2

$201110 \mathrm{v} * 24 \mathrm{c}$

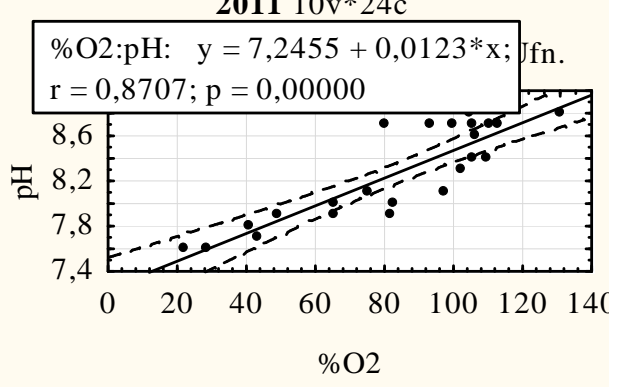

Rys. 2. Korelacje $\mathrm{pH}$ i $\% \mathrm{O}_{2}$ dla okresów wegetacyjnych wybranych lat wielolecia 2000-2014

Fig. 2. The correlations between $\mathrm{pH}$ and $\% \mathrm{O}_{2}$ for vegetation seasons of selected years in period 2000-2014

Uzyskane podczas analizy statystycznej równania regresji opisujące badaną zależność w poszczególnych latach, pozwoliły na określenie wartości współczynnika empirycznego a (równanie 1), na podstawie którego dokonuje się obliczenia wartości wskaźnika ITS. W okresie badawczym wartość tego współczynnika oscylowała w zakresie wartości 0,006 - 0,019 (tab. 4). W ten sposób równanie (1) zostało dostosowane do warunków przebiegu eutrofizacji w Zbiorniku Dobczyckim.

Wskaźniki ITS obliczone według równania (1) z uwzględnieniem uzyskanych wartości współczynnika $a$, pozwoliły ocenić stan trofii w poszczególnych latach okresu 2000-2014. Prześledzono dynamikę zmian oraz określono status troficzny Zbiornika Dobczyckiego (tab. 4). Badane wielolecie odznaczało się dość wysokim stanem troficznym, stwierdzono stan graniczny zaawansowanej mezotrofii i początkowej eutrofii. 
Tabela 4. Ocena stanu trofii na podstawie wartości współczynnika ITS (M-mezotrofia, E-eutrofia)

Table 4. Trophic state assessment based on ITS index (M-mesotrophy, E-eutrophy)

\begin{tabular}{|c|c|c|c|}
\hline Okres badawczy & $\begin{array}{l}\text { Współczynnik } \\
\text { empiryczny } a\end{array}$ & ITS & Ocena trofii \\
\hline 2000 & 0,011 & 8,47 & $\mathrm{E}$ \\
\hline 2001 & 0,019 & 8,25 & $\mathrm{E}$ \\
\hline 2002 & 0,008 & 8,30 & $\mathrm{E}$ \\
\hline 2003 & 0,007 & 8,09 & M \\
\hline 2004 & 0,010 & 8,14 & $\mathrm{E}$ \\
\hline 2005 & 0,012 & 8,13 & $\mathrm{E}$ \\
\hline 2006 & 0,012 & 8,46 & $\mathrm{E}$ \\
\hline 2007 & 0,006 & 8,17 & $\mathrm{E}$ \\
\hline 2008 & 0,009 & 8,38 & $\mathrm{E}$ \\
\hline 2009 & 0,009 & 8,42 & $\mathrm{E}$ \\
\hline 2010 & 0,015 & 8,19 & $\mathrm{E}$ \\
\hline 2011 & 0,012 & 8,47 & $\mathrm{E}$ \\
\hline 2012 & \multicolumn{3}{|c|}{ wykluczony z analiz } \\
\hline 2013 & 0,010 & 8,51 & $\mathrm{E}$ \\
\hline 2014 & 0,011 & 8,44 & $\mathrm{E}$ \\
\hline 2000-2014 & 0,010 & 8,30 & $\mathbf{E}$ \\
\hline
\end{tabular}

Wieloletnią dynamikę zmian stanu troficznego Zbiornika Dobczyckiego przedstawiono na rysunku 3 .

Analiza dynamiki rozwoju procesu eutrofizacji w ciągu ostatnich 15 lat pokazuje, że Zbiornik Dobczycki charakteryzuje się wysokim, a przy tym stabilnym stanem troficzności. Wartości wskaźnika ITS oscylują na poziomie zaawansowanej mezotrofii i początkowej eutrofii. Wyraźnie widać że lata z podwyższoną trofią występują cyklicznie, a od 2009 r. częstość ich występowania wzrasta.

Uzyskane wyniki oceny stanu troficznego Zbiornika Dobczyckiego, jako zbiornika w początkowej fazie eutrofii, dobrze korelują z wynikami badań innych autorów. Dla przykładu, Bednarz i in. [4] piszą, że w Zbiorniku Dobczyckim zakwity pojawiały się już od momentu jego utworzenia, choć $\mathrm{z}$ umiarkowaną intensywnością. $\mathrm{O}$ przejawach eutrofizacji od samego początku wspomina też Mazurkiewicz-Boroń [17]. Według Balcerzaka i Wisz [3] w 1988 r. tylko $3 \%$ badanych wód zasilających Zbiornik odpowiadało I klasie czystości, a badania przed jego utworzeniem oraz po rozpoczęciu eksploatacji 
sugerowały zagrożenie silną eutrofizacją wywołaną obecnością biogenów. W 2009 r. Balcerzak [2] pisał, że ocena stanu trofii Zbiornika Dobczyckiego w latach 1995-2000 wskazywała na eutrofię jego wód. Na podstawie badań z 2003 r. Pawełek i Spytek [22] pisali, że stan jakości bezpośrednich dopływów (Ratanicy, Brzezówki, Dębnika, Wolnicy) nie stwarza zagrożenia dla jakości wód Zbiornika. Są nim natomiast ładunki biogenów wnoszone przez Rabę. Mazurkiewicz-Boroń [17] pisze że efekt przeżyźnienia tym spowodowany utrzymuje się przez wiele lat. Autorka stwierdza też, że napełnienie Zbiornika wodami wykazującymi podwyższoną trofię oraz bardzo wysoka kumulacja fosforu i azotu (odpowiednio do 82\% i do 75\%) to czynniki dodatkowo przyśpieszające eutrofizację. Wykorzystanie wskaźnika ITS w badaniach przeprowadzonych w 2002 i 2004 r. przez Kowalczyk [12] również wskazało eutrofię. Wyniki te pozostają zgodne $\mathrm{z}$ oceną zaprezentowaną $\mathrm{w}$ niniejszym artykule i potwierdzają wiarygodność wyników oceny uzyskanej na podstawie zastosowanego wskaźnika ITS.

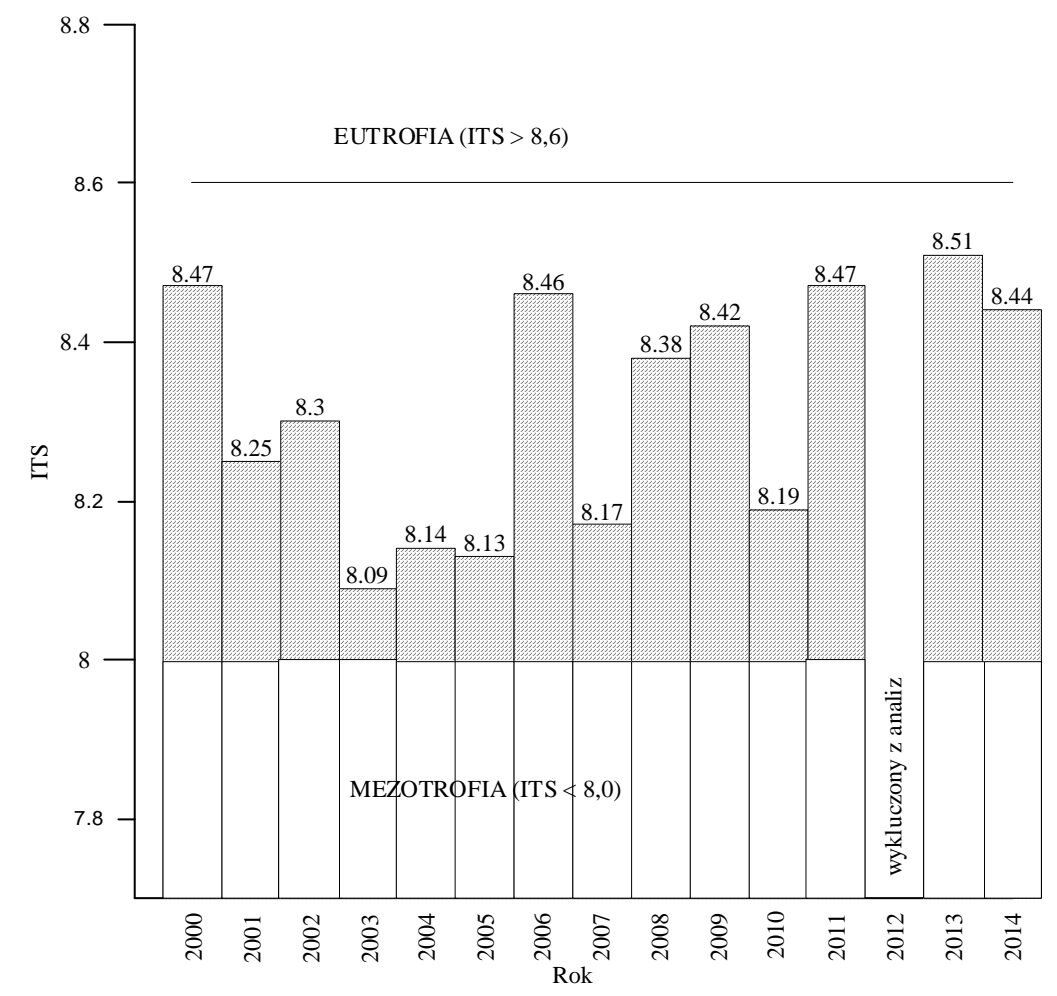

Rys. 3. Dynamika wskaźnika ITS w okresie badawczym 2000-2014

Fig. 3. The dynamism of ITS index in analyzed period 2000-2014 
Wieloletnia dynamika zmian trofii Zbiornika ustalona w toku przeprowadzonych badań, pozwala wnioskować, że mimo różnic w corocznych wartościach wskaźnika ITS Zbiornik Dobczycki od 15 lat znajduje się w stabilnym stanie ekologicznym, definiowanym jako zaawansowana mezotrofia lub początkowa eutrofia. Charakteryzuje się przy tym ogólnie dobrą jakością wody i przydatnością do zaopatrzenia ludności w wodę do spożycia, co świadczy o tym, że od wielu lat pozostaje w stanie homeostazy.

\section{Podsumowanie i wnioski}

Integralny wskaźnik troficzności ITS jest wygodnym narzędziem do oceny stanu trofii wód. Ze względu na powszechną dostępność parametrów na których bazuje (pH i zawartość tlenu) może być stosowany zarówno do oceny aktualnego stanu trofii wód powierzchniowych, jak i oceny sytuacji dawniejszej, kiedy to monitoring tradycyjnych wskaźników troficzności nie był prowadzony. Ponadto może on stanowić podstawę do formułowania modeli prognostycznych eutrofizacji. Ocena na podstawie tego wskaźnika jest łatwa i szybka, nie wymaga od badacza stosowania wyszukanych technik jak w przypadku oceny na podstawie wskaźników hydrobiologicznych.

Podjęty w artykule problem jest istotny z punktu widzenia konieczności realizacji stałego monitoringu stanu troficznego zbiorników zaporowych szczególnie podatnych na eutrofizację, a wykorzystywanych jako rezerwuary wody pitnej dla dużych aglomeracji miejskich. Na podstawie przeprowadzonych analiz sformułowano następujące wnioski szczegółowe.

1. Możliwość zastosowania wskaźnika troficzności ITS jako dostępnego, łatwego i taniego narzędzia monitoringu stanu troficznego Zbiornika Dobczyckiego, została potwierdzona analizą korelacyjno-regresyjną wieloletnich danych monitoringowych.

2. Najbardziej miarodajnym okresem do określania trofii na podstawie integralnego wskaźnika troficzności ITS jest sezon wegetacyjny. Mimo tego wskazana jest ocena na podstawie danych dla okresu całorocznego, ponieważ wskaźnik ITS odzwierciedla de facto roczny bilans procesów produkcji i rozkładu biomasy roślinności wodnej. Tym bardziej, że różnica między wartościami współczynników korelacji charakteryzującymi siłę związku między składnikami wskaźnika ITS w okresie wegetacji i w ciągu całego roku jest nieznaczna (odpowiednio 0,70 i 0,64 ).

3. $\mathrm{W}$ analizach korelacji $\mathrm{pH}$ i nasycenia wody tlenem uwzględniono cały profil badawczy, tj. warstwę powierzchniową, warstwę zlokalizowaną $3 \mathrm{~m}$ pod powierzchnią oraz warstwę naddenną. Wybór takiego układu warstw jako optymalnego wynika $\mathrm{z}$ faktu występowania w Zbiorniku Dobczyckim strefy fotycznej na głębokości 2 - $10 \mathrm{~m}$ (przy średniej $11 \mathrm{~m}$ ), a także pionowych migracji fitoplanktonu. 
4. Wieloletnia (2000-2014) dynamika procesu eutrofizacji wskazuje na ustabilizowanie się statusu troficznego na poziomie początkowego stadium eutrofii. Użytkowe właściwości wody wyrażone odpowiednimi wartościami parametrów jakości wód utrzymują się przy tym na wymaganym poziomie. Oznacza to, że bez względu na swój status troficzny Zbiornik Dobczycki znajduje się w stanie homeostazy.

5. Wyniki oceny stanu troficznego Zbiornika Dobczyckiego metodą wykorzystującą integralny wskaźnik troficzności ITS dobrze korelują z wynikami ocen innych autorów spotykanymi w literaturze. Potwierdza to możliwość stosowania wskaźnika ITS do regularnego monitoringu stanu troficznego z dowolną częstotliwością oraz śledzenia bieżących zmian.

\section{Literatura}

[1] Adamczyk W., Jachimowski A.: Wpływ składników biogennych na jakość i eutrofizację powierzchniowych wód płynących, stanowiących źródło wody pitnej Krakowa. ŻYWNOŚĆ. Nauka. Technologia. Jakość, 2013, 6 (91), s. 175-190.

[2] Balcerzak W.: Eutrofizacja wód stojących - prognozowanie i wpływ na technologię uzdatniania wody. Politechnika Krakowska, Seria Inżynieria Środowiska 2009, Monografia 373, Kraków.

[3] Balcerzak W., Wisz A.: Zagrożenie eutrofizacją wód zbiornika zaporowego Dobczyce. Ochrona Środowiska 1991, 1 (42), s. 27-29.

[4] Bednarz T., Starzecka A., Mazurkiewicz-Boroń G.: Procesy mikrobiologiczne towarzyszące glonowym i sinicowym zakwitom wody. Wiadomości Botaniczne 2002, 46(1/2), s. 45-55.

[5] Cebulska M., Szczepanek R., Twardosz R.: Rozkład przestrzenny opadów atmosferycznych w dorzeczu górnej Wisły. Opady średnie roczne (1952-1981). WIS PK, IGiGP UJ, Kraków 2013.

[6] Geoportal. Główny Urząd Geodezji i Kartografii, http://mapy.geoportal.gov.pl/ imap/, \{dostęp: 10.03.2016 r. \}

[7] Gruca-Rokosz R., Koszelnik P., Tomaszek J. A.: Ocena stanu troficznego trzech nizinnych zbiorników zaporowych Polski południowo-wschodniej. Inżynieria Ekologiczna 2011, Nr 26, s. 196-205.

[8] IMGW. SERWIS POGODOWY IMGW-PIB, http://www.pogodynka.pl/polska/ dane klimatyczne/, \{dostęp: 10.03.2016 r.\}.

[9] Jakubiak M., Śliwka M.: Zbiornik i elektrownia wodna na rzece Rabie w Dobczycach. Materiały konferencyjne, Zielone Prądy w Edukacji II, Edycja 2. Wyd. ArtTekst, Kraków 2006.

[10] Jodłowski A., Gutkowska E.: Ocena stanu troficznego wód Zbiornika Sulejowskiego na podstawie indeksu Carlsona. Inżynieria i Ochrona Środowiska 2012, t. 15 , nr 4, s. 341-351.

[11] Kajak Z.: Hydrobiologia-limnologia. Ekosystemy wód śródlądowych. Wydawnictwo Naukowe PWN. Warszawa 2001.

[12] Kowalczyk E.: Trophic State Assessment of Dobczyce Reservoir. Geomatics and Environmental Engineering 2010, Volume 4, Number 4, s. 97-104. 
[13] Kowalewski Z.: Metody oceny stanu troficznego wód powierzchniowych. Materiały Krakowskiej Konferencji Młodych Uczonych 2006, T. IV, s. 343-351.

[14] Kowalewski Z.: Weryfikacja możliwości zastosowania integralnego kryterium do oceny stanu troficznego wód płynących. Rozprawa doktorska, Kraków 2012.

[15] Kuczyńska-Kippen N., Messyasz B., Nagengast B.: Charakterystyka hydrobiologiczna wód jeziora Lubaskiego Dużego na tle badań wieloletnich (1991-2002). Roczniki Akademii Rolniczej w Poznaniu - CCCLXIII (2004), s. 167-174.

[16] KZGW: Prognoza oddziaływania na środowisko dla warunków korzystania z wód zlewni rzeki Raby (od źródeł do ujścia rzeki do zbiornika Dobczyce). Świdnica 2014.

[17] Mazurkiewicz-Boroń G.: Eutrofizacja - przyczyny i skutki. [W:] Starmach J., Mazurkiewicz-Boroń G. (red.): Zbiornik Dobczycki, ekologia - eutrofizacja - ochrona. Zakład Biologii Wód PAN, Kraków 2000, s. 225-231.

[18] Maksimowicz-Ajchel A.: Wstęp do statystyki. Metody opisu statystycznego. Wydawnictwo Uniwersytetu Warszawskiego, 2007.

[19] Mej E., Lechowski Z.: Wpływ czynników zewnętrznych na wzrost sinic i syntezę toksyn. Wiadomości Botaniczne 2000, 44(1/2), s. 35-49.

[20] Neverova-Dziopak E.: Podstawy zarządzania procesem eutrofizacji antropogenicznej. Wydawnictwa AGH, Kraków 2010.

[21] Panek P.: Wskaźniki biotyczne stosowane w monitoringu wód od czasu implementacji w Polsce Ramowej Dyrektywy Wodnej. Przegląd Przyrodniczy XXII, 3(2011), s. 111-123.

[22] Pawełek J., Spytek M.: Substancje biogenne w dopływach Zbiornika Dobczyckiego. Infrastruktura i Ekologia Terenów Wiejskich, Nr 4/2005, s. 99-113.

[23] Rybicki S. A.: Ochrona zbiorników zaporowych przed zanieczyszczeniem. Ochrona Środowiska 1991, 1(42), s. 13-16.

[24] RZGW w Krakowie, http://www.krakow.rzgw.gov.pl/index.php?option=com_ content $\&$ view=article $\&$ id=110:zbiornik-wodny-dobczyce $\&$ catid=40\&Itemid=239 \&lang=pl, \{dostęp: 10.03.2016 r. $\}$.

[25] Toporowska M., Pawlik-Skowrońska B.: Struktura fitoplanktonu hipertroficznego Jeziora Syczyńskiego obciążonego zakwitami sinic (wschodnia Polska). Fragmenta Floristica et Geobotanica Polonica 2011, 18(2), s. 409-426.

[26] Vollenweider R. A., Giovanardi F., Montanari G., Rinaldi A. 1998. Characterization of the trophic conditions of marine coastal waters with special reference to the NW Adriatic Sea: proposal for a trophic scale, turbidity and generalized water quality index. Environmetrics 1998, Vol. 9, s. 329-357.

[27] WIOŚ w Krakowie: Wyniki Państwowego Monitoringu Środowiska Województwa Małopolskiego z lat 2000-2014.

[28] WIOŚ w Krakowie: Badania i ocena stanu rzek, http://www.krakow.pios.gov.pl/ monitoring/rzeki.php, \{dostęp: 16.03.2016 r., 17.03.2016 r.\}.

[29] Zimoch I.: Symulacja wpływu oczyszczalni ścieków w Myślenicach na eutrofizację wód zbiornika „Dobczyce”. Ochrona Środowiska 2001, 2(81), s. 21-24.

[30] Zimoch I., Kłos M.: Zastosowanie technik komputerowych do prognozowania eutrofizacji wód powierzchniowych na przykładzie zbiornika zaporowego „Dobczyce". Ochrona Srodowiska 2003, Rok 25, Nr 3, s. 73-76. 


\section{VERIFICATION OF THE POSSIBILITY OF ITS INDEX APPLICATION TO ASSESS THE TROPHIC STATE OF THE DOBCZYCKI RESERVOIR}

\section{S u m m a r y}

In the last few years the problem of eutrophication has become serious not only in the stagnant waters but also in running waters. The eutrophication focuses the great attention especially when concerns the water used for municipal water supply. The Dobczycki Reservoir which is the subject of the article is such type of dam reservoir. The water intake for community of Cracow is located there. In the literature we can find many opinions that the water of Dobczycki Reservoir has always been vulnerable to eutrophication due to the loads of nutrients transporting by Raba. The problem of assessing the degree of Dobczycki Reservoir's eutrophication was taken because of its utilitarian meaning, not only for cognitive reasons. It demands reliably and detail analysis of measurement data obtained from monitoring to assess the development of the process. The results of long-term period of observations used in analysis made the assessment reliable, allowed to spot some rules of the process and its dynamism. On the basis of analysis it is possible to forecast probable direction of development of the process. The assessment of trophic state was made using the Index of Trophical State ITS. It is one of the more widely using aggregated index. The practice showed that the methods based on threshold values of singular parameters of eutrophication do not reflect exactly the trophic state of water and often provide to not quite correct conclusions. The ITS is the index based on correlation of $\mathrm{pH}$ and oxygen content in water, the parameters indirectly expressing the gas balance in water changing together with the balance of production and decomposition of organic matter. This index not require a specific measurements and may be used as a universal method of assessing the trophic state of Dobczycki Reservoir, that was stated by the researches presented in this paper.

Keywords: Dobczycki Reservoir, eutrophication, Index of Trophical State (ITS), statistical analysis

DOI:10.7862/rb.2016.166

Przestano do redakcji: 01.05.2016 r.

Przyjęto do druku: 28.06.2016 r. 